\title{
Epidermal growth factor suppresses induction by progestin of the adhesion protein desmoplakin in T47D breast cancer cells
}

\author{
Haiyan Pang ${ }^{1}$, Brian G Rowan², Mariam Al-Dhaheri' ${ }^{2}$ and Lee E Faber ${ }^{3}$ \\ ${ }^{1}$ Department of Pediatrics, University of Michigan, Ann Arbor, Michigan, USA \\ ${ }^{2}$ Department of Biochemistry and Molecular Biology, Medical College of Ohio, Toledo, Ohio, USA \\ ${ }^{3}$ Department of Physiology and Molecular Medicine, Medical College of Ohio, Toledo, USA \\ Corresponding author: Lee E Faber (e-mail: Ifaber@mco.edu)
}

Received: 19 Jun 2003 Revisions requested: 31 Jul 2003 Revisions received: 2 Dec 2003 Accepted: 26 Feb 2004 Published: 18 Mar 2004

Breast Cancer Res 2004, 6:R239-R245 (DOI 10.1186/bcr780)

(c) 2004 Pang et al., licensee BioMed Central Ltd. This is an Open Access article: verbatim copying and redistribution of this article are permitted in all media for any purpose, provided this notice is preserved along with the article's original URL.

\begin{abstract}
Introduction: Although the effects of progesterone on cell cycle progression are well known, its role in spreading and adhesion of breast cancer cells has not attracted much attention until recently. Indeed, by controlling cell adhesion proteins, progesterone may play a direct role in breast cancer invasion and metastasis. Progesterone has also been shown to modulate epidermal growth factor (EGF) effects in neoplasia, although EGF effects on progesterone pathways and targets are less well understood. In the present study we identify an effect of EGF on a progesterone target, namely desmoplakin.

Methods: Initially flow cytometry was used to establish the growing conditions and demonstrate that the T47D breast cancer cell line was responding to progesterone and EGF in a classical manner. Differential display RT-PCR was employed to identify differentially expressed genes affected by progesterone

and EGF. Western and Northern blotting were used to verify interactions between EGF and progesterone in three breast cancer cell lines: T47D, MCF-7, and ZR-75.

Results: We found the cell adhesion protein desmoplakin to be upregulated by progesterone - a process that was suppressed by EGF. This appears to be a general but not universal effect in breast cancer cell lines.

Conclusion: Our findings suggest that progesterone and EGF may play opposing roles in metastasis. They also suggest that desmoplakin may be a useful biomarker for mechanistic studies designed to analyze the crosstalk between EGF and progesterone dependent events. Our work may help to bridge the fields of metastasis and differentiation, and the mechanisms of steroid action.
\end{abstract}

Keywords: breast cancer, desmoplakin, epidermal growth factor, differential display RT-PCR, progesterone

\section{Introduction}

Among the peptide growth factors that are active in breast glandular cell proliferation, epidermal growth factor (EGF) is thought to play a role in tumor development. EGF receptor overexpression has been detected in a variety of human breast cancer cells [1]. It has been shown to modulate the growth of mammary gland cells as well as the proliferation of cultured hormone-sensitive human breast cancer cells [2]. EGF has potent growth-promoting effects in mammary epithelium, stimulating DNA synthesis and cellular proliferation [3]. Much evidence supports the view that peptide growth factor pathways are intimately involved in the proliferative response of breast cancer cells $[4,5]$.

On the other hand, progesterone has important and complex effects in the mammary gland. In mouse mammary epithelium it stimulates proliferation, which eventually culminates in glandular development. Progestins may be used to treat human breast cancer, mammary fibrosis, and endometrial carcinoma [6-8]. In breast cancer therapy, for example, $30-40 \%$ of patients whose tumors contain proges-

$\mathrm{bp}=$ base pairs; EGF = epidermal growth factor; ERK = extracellular signal-regulated protein kinase; FBS = fetal bovine serum; GAPDH = glyceraldehyde-3-phosphate dehydrogenase; $\mathrm{PCR}=$ polymerase chain reaction; $\mathrm{RT}=$ reverse transcriptase; $20 \times \mathrm{SSC}=3.0 \mathrm{M}$ sodium chloride, $0.3 \mathrm{M}$ sodium citrate buffer. 
terone receptors respond to synthetic progestins such as R5020, suggesting that progestins are as effective in suppressing tumor growth as the antiestrogen tamoxifen [8].

For these reasons, the effects of progestins and EGF on the T47D breast cancer cell line were re-examined using flow cytometry. We found that EGF blocked progestin suppression of S-phase induction. We then employed differential display RT-PCR [9] to identify differentially expressed genes affected by progestin and EGF.

In the study a progestin and EGF responsive gene, desmoplakin, was identified. Loss of desmoplakin, a cell adhesion molecule, has been implicated in breast cancer metastasis. The expression of desmoplakin was positively regulated by progestin and negatively regulated by EGF. Furthermore, EGF reversed progestin upregulation of desmoplakin. This suggests a role for progestin-EGF interaction not only in cell cycle progression but also in metastasis. Indeed, the mitogen EGF may be thought of as having an impact on progestin-dependent biologic responses.

\section{Methods}

EGF, RPMI-1640, L-glutamine, and antibiotics/antimycotics were purchased from either Sigma (St Louis, MO, USA) or Invitrogen (Grand Island, NY, USA). Fetal bovine serum (FBS) was obtained from HyClone (Salt Lake City, UT, USA). The synthetic progestin R5020 (17,21-dimethyl19nor-4,9-pregnadiene-3,20-dione) and [ $\left.{ }^{32} \mathrm{P}\right]$-dCTP were purchased from Dupont/NEN (Boston, MA, USA). Delta ${ }^{\mathrm{TM}}$ RNA Fingerprinting Kit was purchased from Clontech (Palo Alto, CA, USA). TA cloning kit was purchased from Invitrogen (San Diego, CA, USA). AmpliCycle ${ }^{\mathrm{TM}}$ Sequencing Kit was purchased from Perkin Elmer (Foster City, CA, USA). RNA State-60 Kit was purchased from Tel-Test Inc. (Friendswood, TX, USA). DECA probe template-glyceraldehyde-3-phosphate dehydrogenase (GAPDH)-mouse was purchased from Ambion (Austin, TX, USA). Random primers DNA labeling kit was purchased from Gibco BRL (Grand Island, NY, USA). Mouse monoclonal antibody to desmoplakin I and II was purchased from Maine Biotechnology Services Inc. (Portland, ME, USA). Antimouse IgG-HRP was purchased from Santa Cruz Biotechnology Inc. (Santa Cruz, CA, USA). Actin (C-11), goat polyclonal antibody, horseradish peroxidase streptavidin, biotinylated antimouse $\lg G$, and biotinylated antigoat IgG were purchased from Vector Laboratories (Burlingame, CA, USA). Finally, $\left.{ }^{[33} \mathrm{P}\right]$-adenosine triphosphate and enhanced chemiluminescence reagents were purchased from Amersham Life Science (Arlington Heights, IL).

\section{Cell culture of T47D cells for flow cytometry and RNA isolation}

T47D breast cancer cells were purchased from the American Type Culture Collection (Rockville, MD, USA). six-well plates and seeded at $0.5 \times 10^{6}$ cells/well in RPMI1640 medium. The medium was supplemented with $10 \%$ FBS, $5 \mathrm{mg} / \mathrm{ml}$ insulin, $2 \mathrm{mmol} / \mathrm{l} \mathrm{L-glutamine,} \mathrm{and} 1 \%$ the antibiotic/antimycotic mixture.

\section{Cell culture of various breast cancer cell lines for Western blot analysis}

T47D cells were maintained in RPMl-1640 media containing insulin $(5 \mu \mathrm{g} / \mathrm{ml})$, FBS (10\%), and penicillin/streptomycin $(1 \%)$ at $37^{\circ} \mathrm{C}$ in a $5 \%$ humidified incubator. ZR-75 and MCF-7 breast cancer cells were maintained in Dulbecco's modified Eagle medium containing FBS (5\%) and penicillin/streptomycin (1\%) at $37^{\circ} \mathrm{C}$ in a $5 \%$ humidified incubator. At $80 \%$ of confluency, cells were trypsinized for $5 \mathrm{~min}$ at $37^{\circ} \mathrm{C}$, washed with phosphate-buffered saline, and $0.75 \times 10^{6}$ cells were plated in $60 \times 15 \mathrm{~mm}$ plates in media containing $5 \%$ FBS that was charcoal stripped to remove endogenous steroids. Cells were then incubated with vehicle, R5020 $\left(1 \times 10^{-8} \mathrm{~mol} / \mathrm{l}\right)$, EGF $\left(1 \times 10^{-8} \mathrm{~mol} / \mathrm{l}\right)$, or R5020 plus EGF for 48 hours.

\section{Flow cytometric analysis}

Cell cycle phase distribution was determined by analytical DNA flow cytometry. Cells were incubated for 48 hours with $100 \mathrm{nmol} / \mathrm{l} \mathrm{R} 5020,10 \mathrm{nmol} / \mathrm{l}$ EGF, or $100 \mathrm{nmol} / \mathrm{l} \mathrm{R} 5020$ plus $10 \mathrm{nmol} / \mathrm{I}$ EGF. Treated and control cells were harvested and adjusted to $5 \times 10^{6} \mathrm{cells} / \mathrm{ml}$. Nuclei were stained with propidium iodine according to the method of Vindelov and coworkers [10]. A Coulter Electronics EPCS ${ }^{\circledR}$ Elite Flow Cytometer (Beckman Coulter, Hialeah, FL, USA) was used to analyze DNA. Normal male lymphocytes served as working standard. The percentage of cells in the various phases was calculated by use of multicycle software, as is standard for our pathology department. Statistical analysis of the data from the various flow cytometric experiments was carried out using Microsoft Excel software.

\section{Differential display RT-PCR}

Differential display RT-PCR was conducted as described using the commercially available Delta ${ }^{\text {TM }}$ RNA Fingerprinting Kit. Briefly, $2 \mu \mathrm{g}$ total RNA was reverse transcribed with $1 \mu \mathrm{mol} / /$ oligomer used as the $3^{\prime}$ primer. cDNAs were radiolabeled with [33P]-dATP and amplified by PCR with arbitrary $\mathrm{P}$ and anchor $\mathrm{T}$ primers provided in the kit according to the following program: 1 cycle $-5 \mathrm{~min}$ at $94^{\circ} \mathrm{C}, 5 \mathrm{~min}$ at $40^{\circ} \mathrm{C}$ and $5 \mathrm{~min}$ at $68^{\circ} \mathrm{C} ; 2$ cycles $-2 \mathrm{~min}$ at $94^{\circ} \mathrm{C}, 5 \mathrm{~min}$ at $40^{\circ} \mathrm{C}, 5 \mathrm{~min}$ at $68^{\circ} \mathrm{C} ; 25$ cycles $-1 \mathrm{~min}$ at $94^{\circ} \mathrm{C}, 1 \mathrm{~min}$ at $60^{\circ} \mathrm{C}$ and $2 \mathrm{~min}$ at $68^{\circ} \mathrm{C}$; and concluding with one cycle $-7 \mathrm{~min}$ at $68^{\circ} \mathrm{C}$, for extension. The reaction products were then separated by electrophoresis on a $6 \%$ nondenatured polyacrylamide gel and identified by autoradiography. Candidate bands, expressed differentially in cells treated with progestin, EGF, and progestin plus EGF, as well as control cells, were excised from the gel, and then eluted and reamplified by PCR according to the above PCR program. 


\section{Sequence analysis}

Reamplified PCR products confirmed by Northern blot were cloned directly into the pCRII vector from the TA cloning kit according to the manufacturer's instructions. Colonies containing the insert were selected for sequencing by using AmpliCycle ${ }^{\mathrm{TM}}$ Sequencing Kit according to the manufacturer's instructions. Sequence homology with known genes was sought by searching the US National Institutes of Health GenBank database.

\section{RNA isolation and Northern blot analysis}

Cells grown to near confluency were incubated for 48 hours with $10 \mathrm{nmol} / \mathrm{l} \mathrm{R} 5020$ or $10 \mathrm{nmol} / \mathrm{l}$ EGF in medium containing 10\% charcoal-treated FBS. Total RNA was isolated from R5020, EGF, and R5020 plus EGF treated cells, as well as control cells, by use of RNA State60 Kit according to the manufacturer's instructions.

Total RNA $(10 \mu \mathrm{g})$ was subjected to electrophoresis in a $1 \%$ agarose gel containing formaldehyde, and then transferred to Optitran ${ }^{\circledR}$ BA-S supported nitrocellulose membranes with a Turboblotter ${ }^{\mathrm{TM}}$ Rapid Downward Transfer System (Schleicher \& Schuell, Keene, NH, USA) using $20 \times$ SSC (3.0 M sodium chloride, $0.3 \mathrm{M}$ sodium citrate). Blot hybridization was done in $5 \times$ SSC, $50 \%$ formamide, $2 \times$ Denhardt, $20 \mathrm{mmol} / \mathrm{l} \quad \mathrm{Na}_{2} \mathrm{HPO}_{4}, \quad 0.1 \%$ SDS, $10 \%$ dextran sulfate, and $100 \mu \mathrm{g} / \mathrm{ml}$ salmon testis DNA, with the cDNA probe labeled with [32P]-dCTP using Random Primers DNA Labeling Kit (Gibco BRL, Grand Island, NY, USA). The hybridization was carried out at $37^{\circ} \mathrm{C}$ for 24 hours. The blot was then washed twice with $2 \times$ SSC containing $0.2 \%$ SDS. The blot was exposed to $\mathrm{X}$-ray film at $-70^{\circ} \mathrm{C}$. The autoradiography film of the Northern blot was scanned with a ScanJet 3C/T Scanner (Hewlett-Packard, Palo Alto, CA, USA). To compare the level of desmoplakin induction, the signal intensity of desmoplakin was divided by the value for the GAPDH. The control sample was set to 1 and the fold difference for treatments relative to control was plotted. Statistical analysis for the fold of induction was determined by t-test.

\section{Western blot analysis}

Cells were harvested in cold phosphate-buffered saline $(1 \times)$ and lysed by incubating the cell pellet with high-salt lysis buffer (Tris, pH 7.5 [10 mmol/l], $\mathrm{NaCl}$ [400 mmol/l], EDTA [1 mmol/l], EGTA [1 mmol/l], SDS [1\%], Triton [0.1\%], PMSF [0.1 mmol/l], and a protease inhibitor cocktail [Sigma]) for $10 \mathrm{~min}$ in ice. Twenty-five micrograms of the cellular extract was electrophoresed on a $6.5 \%$ or $10 \%$ SDS-PAGE gel for desmoplakin and actin, respectively, and then transferred to nitrocellulose membrane. Western blot analysis was performed by incubating the membranes with antibody against desmoplakin I and II or $\beta$-actin for 14 hours at $4^{\circ} \mathrm{C}$. Secondary antibody was incubated for 1 hour at room temperature, followed by incubation with horseradish peroxidase streptavidin for 1 hour at room
Figure 1

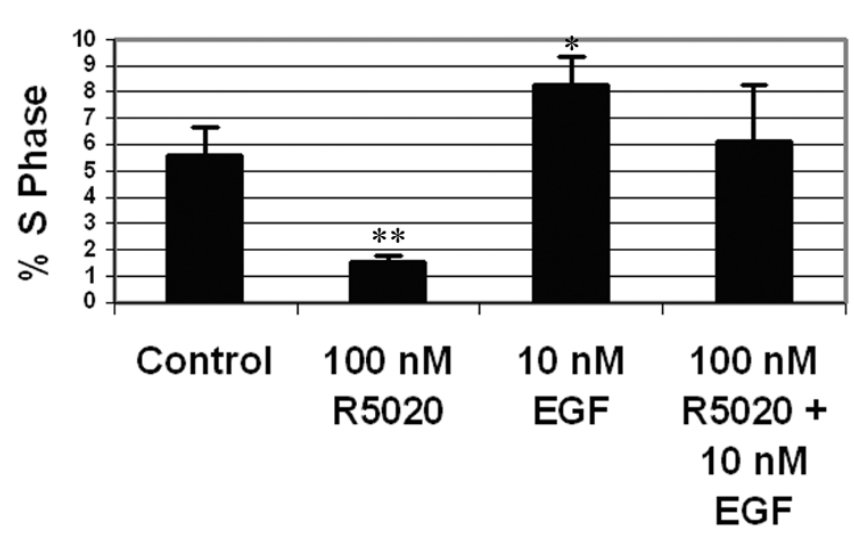

The effects of R5020 and epidermal growth factor (EGF) on S-phase of T47D cells. T47D cells were incubated for 48 hours with $100 \mathrm{nmol} / \mathrm{l}$ R5020, $10 \mathrm{nmol} / / \mathrm{EGF}$, or $100 \mathrm{nmol} / \mathrm{l}$ R5020 plus $10 \mathrm{nmol} / \mathrm{I} \mathrm{EGF}$. Controls received vehicle and were allowed to grow for 48 hours. S-phase was measured by flow cytometry. Each bar is the mean of three individual experiments. Statistical significance was determined using t-test. ${ }^{*} P<0.05,{ }^{* *} P<0.01$, versus control.

temperature. Western blot signals were developed by using enhanced chemiluminescence reagents, and signal intensity was measured using a Kodak Digital Science 1D image analysis software station 440 system. To compare the level of desmoplakin induction among treatments, the signal intensity of desmoplakin was divided by the value for the $\beta$-actin to normalize for protein load. The vehicletreated sample was set to 1 and the fold difference for treatments relative to vehicle was plotted. Statistical analysis for the fold of induction was conducted by using one-way analysis of variance.

\section{Results}

The effect of R5020 and epidermal growth factor on T47D cell cycle progression

To gain insight into EGF-progestin effects, cell cycle phase distribution was determined by flow cytometry. T47D cells were treated for 48 hours with $100 \mathrm{nmol} / \mathrm{l}$ R5020, $10 \mathrm{nmol} / \mathrm{l}$ EGF, and $100 \mathrm{nmol} / \mathrm{l}$ R5020 plus $10 \mathrm{nmol} / \mathrm{I} \mathrm{EGF}$, or vehicle. The proportion of cells in Sphase decreased ( $P<0.01$ compared with control) when treated with R5020, and increased when treated with EGF ( $P<0.05$ compared with control). The effect of R5020 was reversed by EGF (Fig. 1), with EGF restoring the percentage of cells in $S$ phase to values similar to those of controls. This finding indicated that R5020 inhibited and EGF stimulated T47D cell cycle progression.

\section{Identification and sequence of desmoplakin}

In a subsequent series of experiments, RNA samples were prepared from T47D cells incubated for 48 hours with R5020, EGF, or R5020 plus EGF (all at $10 \mathrm{nmol} / \mathrm{l}$ ), as well as cultured control cells. The RNA was used to synthesize 
(a)

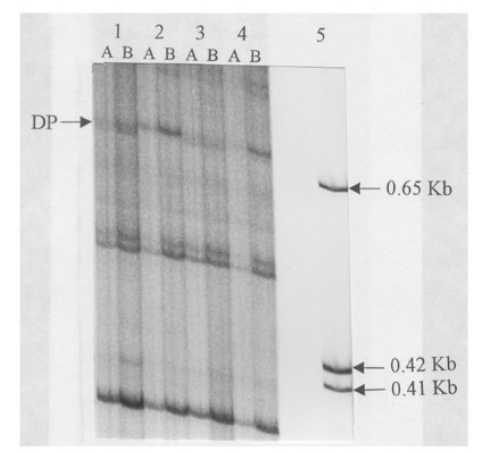

(b)

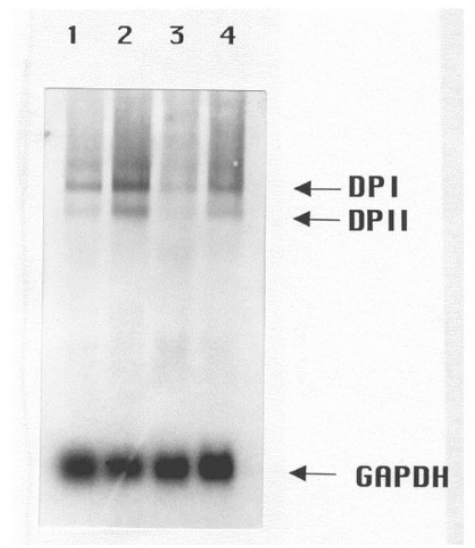

(c)

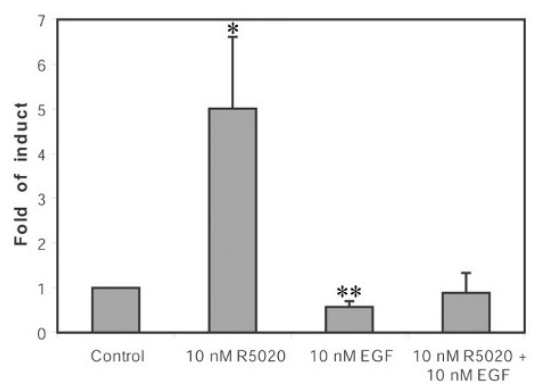

Differential display and Northern blot analysis of R5020 and epidermal growth factor (EGF) regulation of desmoplakin I (DPI) and II (DPII) in T47D cells. (a) Autoradiography of a representative differential display RT-PCR acrylamide gel. ${ }^{33}$ P-labeled DNA fragments generated by RT-PCR from RNAs of control T47D cells (lane 1), $10 \mathrm{nmol} / / \mathrm{R} 5020$ treatment (lane 2), $10 \mathrm{nmol} / / \mathrm{EGF}$ treatment (lane 3), and $10 \mathrm{nmol} / \mathrm{l} \mathrm{R} 5020 \mathrm{plus} 10 \mathrm{nmol} / \mathrm{l}$ EGF treatment (lane 4). Each lane contains $5 \mu \mathrm{l} \mathrm{PCR} \mathrm{mixture.} \mathrm{(A)} \mathrm{1:20} \mathrm{dilution} \mathrm{of} \mathrm{RT-PCR} \mathrm{cDNA.} \mathrm{(B)} \mathrm{1:40} \mathrm{dilution} \mathrm{of} \mathrm{RT-PCR} \mathrm{cDNA.} \mathrm{The} \mathrm{arrow}$ indicates desmoplakin (DP). Molecular weight standards of $0.65,0.42$, and $0.41 \mathrm{~kb}$ are indicated in lane 5 . (b) Photograph of a representative Northern blot analysis of DPI and DPII, and glyceraldehyde-3-phosphate dehydrogenase (GAPDH) mRNA expression in T47D cells. Lane 1: control T47D cells were left untreated for 48 hours. Matched sister colonies of T47D cells received 10nmol/l R5020 (lane 2), $10 \mathrm{nmol} / / \mathrm{EGF}$ (lane 3), or $10 \mathrm{nmol} / \mathrm{l}$ R5020 plus $10 \mathrm{nmol} / \mathrm{I} \mathrm{EGF} \mathrm{(lane} \mathrm{4)} \mathrm{for} 48$ hours. Ten micrograms of total RNA was subjected to Northern blot analysis as described in the Methods section. (c) The Northern blot films were scanned. The graphs indicate the fold difference of desmoplakin expression compared with vehicle (set at a value of 1) following measurement of the band intensities. In each independent experiment, the desmoplakin band for each treatment condition was normalized to the GAPDH signal. The experiment was repeated three times and the mean values from these experiments \pm SEM are reported. Statistical significance was determined using t-test. ${ }^{\star} P<0.05,{ }^{\star \star} P<0.01$, versus control.

the corresponding cDNA, which was subsequently used for the differential display PCR reaction. For each pair of primers the differential display was performed twice with cDNAs derived from two sets of RNAs. The expression of one band (800 bp fragment) increased in cells incubated with R5020. It was decreased in cells incubated with R5020 plus EGF, and with EGF alone (Fig. 2a).

To confirm that this fragment expressed differently, the 800 bp DNA fragment was used as a probe to hybridize a membrane containing RNAs from T47D cells incubated with R5020, EGF, R5020 plus EGF (all at $10 \mathrm{nmol} / \mathrm{l}$ ), and control cells. The expression of this RNA increased in cells incubated with R5020. This increase was blocked by coincubation of EGF with R5020 (Fig. 2b). EGF itself had
mRNA. As a control for RNA loading, the membrane was hybridized with a probe to detect GAPDH transcript. The mean fold induction results from three independent experiments are shown in Fig. 2c.

After verification by Northern blot analysis, the $800 \mathrm{bp}$ fragment of cDNA was subcloned into the pCRII vector and sequenced. The derived nucleotide sequence was compared with the GenBank sequences and showed identity to desmoplakin.

In order to confirm the identified gene, a $1100 \mathrm{bp}$ DNA fragment of desmoplakin (a gift from Dr Kathleen Green) was used as a probe to hybridize a RNA membrane. Similar results to those in Fig. 2 were observed (data not shown). 


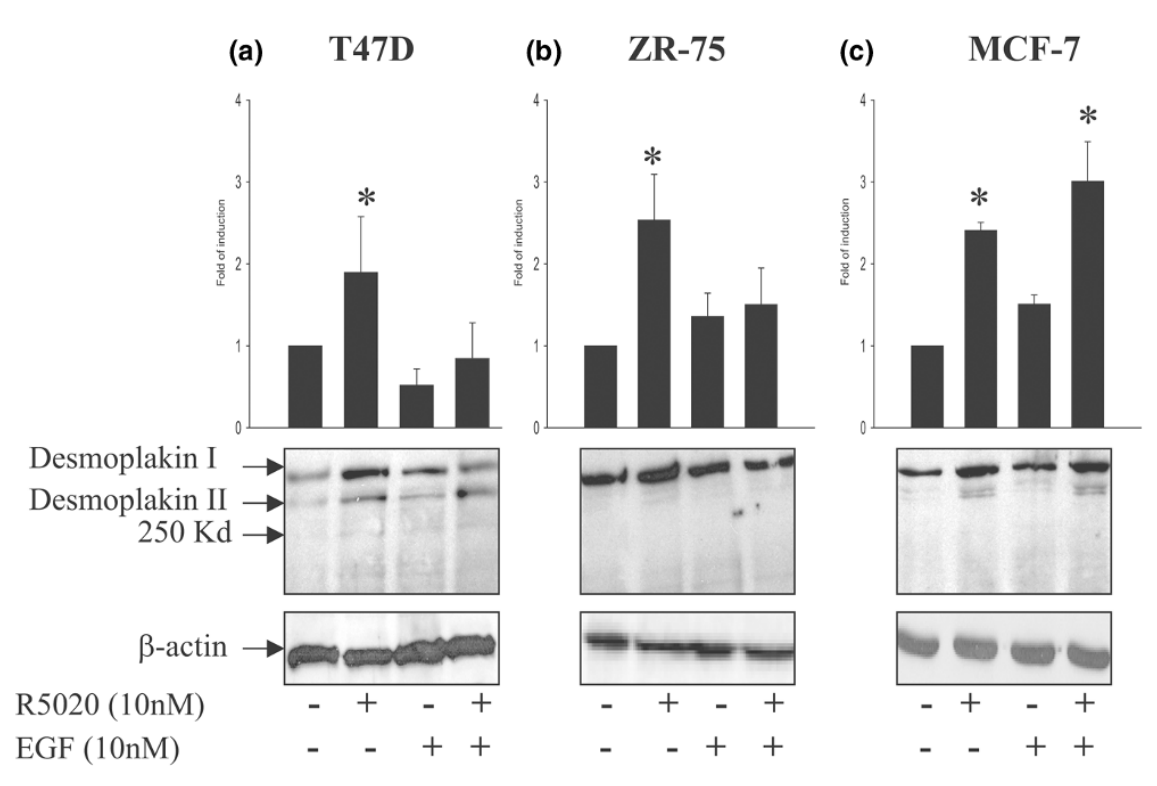

Regulation of desmoplakin expression in breast cancer cell lines by R5020 and epidermal growth factor (EGF). (a) T47D cells were plated in RPMI media containing 5\% stripped serum. (b) ZR-75 and (c) MCF-7 cells were plated in Dulbecco's modified Eagle medium (DMEM) containing 5\% stripped serum. Cells were incubated with vehicle, R5020, EGF, or R5020 plus EGF for 48 hours before preparation of total cellular extract for Western blot analysis with antibody to desmoplakin or $\beta$-actin. The graphs indicate the fold difference of desmoplakin expression compared with vehicle (set at a value of 1) following measurement of Western blot signal intensity by Kodak Image Station 440CF and 1D Image Analysis software. In each independent experiment, duplicate samples for each treatment condition were normalized to the $\beta$-actin levels. The experiment was repeated two times and the mean values from these experiments \pm SEM are reported. Representative Western blots for desmoplakin and $\beta$-actin levels in each cell line are shown below the graphs. ${ }^{*} P<0.05$ versus control (by one-way analysis of variance).

\section{Progestin and epidermal growth factor regulation of desmoplakin protein in breast cancer cells}

To investigate whether the progestin-induced increase in desmoplakin mRNA expression and inhibition by EGF of desmoplakin mRNA expression were reflected in protein expression, and to determine whether this regulation occurred in other breast cancer cell lines, immunoblot analyses for desmoplakin protein were performed on extracts of T47D, ZR-75 and MCF-7 cells. Following 48 hours of exposure of T47D cells to R5020, a clear increase in desmoplakin I and II protein expression was found (Fig. 3a). EGF blocked the R5020-dependent increases in desmoplakin protein. Identical results were obtained with the ZR-75 breast cancer cells (Fig. 3b). Thus, the progestin-induced increased in desmoplakin protein was due to increased mRNA synthesis, and this effect could be blocked by EGF. Similar to T47D and ZR75 cells, progestin also induced desmoplakin protein expression in MCF-7 cells. However, under these conditions EGF was unable to suppress the induction by progestin of desmoplakin protein in the latter cell line (Fig. 3c). The inability of EGF to suppress induction by progestin of desmoplakin in MCF-7 cells was not due to absence of an intact EGF receptor signaling pathway because incubation of cells with $10 \mathrm{nmol} / \mathrm{l}$ EGF resulted in activation of extracellular signal-regulated protein kinase
(ERK) $1 / 2$ within $5 \mathrm{~min}$, as assessed by Western blot analysis with phospho-ERK1/2 antibodies (data not shown).

\section{Discussion}

Our findings, gained after 48 hours of exposure to progestin, are consistent with most clinical observations of inhibition by progestin of cellular proliferation in progestin receptor-positive breast tumors. Cell density, and both the concentration and composition of the serum may be major factors influencing progestin action in cell culture. The conditions of cell culture described in the present study are more similar to those of breast tumors in situ. Under the latter circumstances, cells grow in high densities and are richly supplied with nutrients.

Several laboratories observed a degree of reversal of the effects of progestin on cell proliferation by EGF [11-14]. Some evidence implicates EGF and/or related peptides, including transforming growth factor- $\alpha$, not only in the overall control of proliferation in human breast cancer cells but also specifically in the response to progestins [12].

In these studies, a progestin upregulated gene, desmoplakin, was identified in three independent experiments. The expression of desmoplakin mRNA and protein increased in T47D cells incubated with progestin, and 
decreased in those cells incubated with EGF. This would appear to be a general effect because it was also noted in a second breast cancer cell line (ZR-75). Confounding our observation was the inability of EGF to suppress induction by progestin of desmoplakin in MCF-7 cells. This may be a cell line specific effect or it merely reflect the varying degree of differentiation between the cell lines and/or passage number, or some other unknown reason. Thus, the ability of EGF to suppress induction of desmoplakin by progestin is a general but not universal effect. The differential effect of EGF on desmoplakin induction in these cell lines should provide appropriate models to dissect the molecular mechanisms for crosstalk between the EGF and progesterone receptor signaling pathways. Kester and coworkers [15] found that desmoplakin was induced in T47D cells by progestin in the absence of additional hormones. Those investigators also noted that basic fibroblastic growth factor had no effect, and that induction of desmoplakin mRNA was a slow process, taking 24 hours of exposure to progestin to be measurable. A maximal effect was noted after 2 days of exposure to progestin. Our findings support the notion that EGF and progestin may have opposing effects on differentiation of T47D cells.

Desmoplakin I and II are alternatively spliced products of the same gene $[16,17]$. Desmoplakins are highly related phosphoproteins and are the most abundant constituents of the desmosomal plaque [18-22]. Synthesis of the desmoplakins is a characteristic of certain routes of differentiation, especially of epithelia, in which the appearance of desmosomes correlates with the concomitant expression of cytokeratin filaments that attach to them [23]. A decrease in the amount of desmoplakin may cause abnormal assembly of desmosomes, which results in differences in the adhesive properties of their junctions. It is widely believed that cell division is accompanied by a reduction in cellular adhesives. Therefore, reduction in cellular adhesives may lead to a greater tendency for cells to be released from the primary tumor [24]. The expression of desmoplakin (a marker for epithelial differentiation) along with other epithelial markers in mammary carcinoma cell lines has been negatively correlated with invasion and positively correlated with the differentiation state [25].

The study of desmoplakin expression in a series of rat bladder epithelial cell lines of varying metastatic potential suggests that abnormalities of desmoplakin expression may contribute to tumorigenicity and invasion in bladder carcinoma [26]. In a study of oral squamous cell carcinoma, a negative correlation between desmoplakin staining and loss of differentiation of the primary tumor and degree of invasion was reported [27]. Davies and coworkers [28] reported that loss of desmoplakin might be of potential importance in the progression of breast cancer in vivo from normal tissue to ductal carcinoma in situ, and from
They concluded that loss of desmoplakin in breast cancer is likely to be important in the progression and metastasis of breast cancer in vivo.

Our study compliments recent work conducted by Lin and coworkers $[29,30]$, who isolated the activities of progesterone from the influence of estrogen. To do this they transfected PR A/B in estrogen receptor- and progesterone receptor-negative MDA-MB-231 cells. Surprisingly, they found that progesterone, acting via its receptor, enhanced focal adhesion in transfected cells. Furthermore, they were able to demonstrate isolated progestational effects on target proteins. Both the focal adhesion protein paxillin and the focal adhesion kinase had increased tyrosine phosphorylation under the influence of progesterone. Finally, Lin and coworkers noted that the induction of focal adhesion was dependent upon the activity of the adhesion protein $\beta_{1}$ integrin.

However, somewhat confounding the $\beta_{1}$ integrin story, Dai and coworkers [31] transfected progesterone receptor into endometrial carcinoma cells and demonstrated a decline in $\beta_{1}$ integrin under progestin influence. Certainly, further analysis is warranted, but these studies demonstrate a new and direct biologic effect of progesterone, namely cell adhesion. Our work compliments this in that we have demonstrated the induction of an adhesion protein under progestin control and suppression of this effect by EGF. Of considerable theoretical interest is our observation of a mitogen, in this instance EGF, having a direct impact on a steroid sensitive cascade, which is the converse of the notion of a progestin affecting the EGF dependent process [32].

Although we have not identified the relevant dependent signal transduction cascades, a direct effect of progesterone on EGF dependent pathways at the level of ERK1/2 kinase, SAPK/JNK kinase and STAT (signal transducers and activators of transcription) has been demonstrated by Lange and coworkers [33] and Richer colleagues [34]. This work described crosstalk of mitogen and steroid signal transduction pathways. These pathways may or may not terminate in focal adhesion although this would certainly be of interest for future studies.

The upregulation of desmoplakin expression by progestin may explain the partial role played by progestin in suppressing tumor growth and spread during some breast cancer therapy regimens. Upregulation of desmoplakin expression may be associated with a progestational effect on differentiation. Downregulation of desmoplakin under a dual progestin-EGF balance may relate to invasion and metastasis, thus suggesting a potential role for EGF in metastasis.

\section{Conclusion}

Desmoplakin may well serve as a useful marker for further studies on the mechanism of crosstalk between EGF and 
progestin dependent pathways. Our findings suggest that progesterone and EGF may play opposing roles in metastasis, and suggest that desmoplakin may be a useful biomarker for mechanistic studies designed to analyze the crosstalk between EGF and progestin-dependent events. Desmoplakin could also prove to be a useful marker for further work on adhesion and metastasis. Thus, our work may help to bridge the fields of metastasis, differentiation, and mechanisms of steroid action.

\section{Competing interests}

None declared.

\section{Acknowledgements}

This project was supported by A1-34776 and HD-043171. We wish to thank Marianne Miller Jasper for preparation of the typescript, $\mathrm{Dr}$ Kathleen Green for providing the desmoplakin DNA, and the personnel of the Flow Cytometry Laboratory, Tom Sawyer and Karen Dominico. We also wish to acknowledgment the contribution of Dr PKK Tai in the early aspects of the study and Yatrik Shah for results on the EGF receptor pathway in MCF-7 cells.

\section{References}

1. Murphy LC, Dotzlaw H, Wong MSJ, Miller T, Mrockowski B, Gong $Y$, Murphy $L$ : Epidermal growth factor: receptor and ligand expression in human breast cancer. Semin Cancer Biol 1990, 1:305-315

2. Cupis $A D$, Favoni RE: Oestrogen/growth factor cross-talk in breast carcinoma: a specific target for novel antioestrogens. Trends Pharmacol Sci 1997, 18:245-251.

3. Murphy LI, Sutherland RL, Stead B, Murphy LC, Lazarus L: Progestin regulation of epidermal growth factor receptor in human mammary carcinoma cells. Cancer Res 1986, 46:728-734.

4. Arteaga CL, Osborne CK: Growth factors as mediators of estrogen/antioestrogen action in human breast cancer cells. In Regulatory Mechanisms in Breast Cancer. Edited by Lippman ME and Dickson RB. Boston: Kluwer Academic Publishers; 1991:289-304.

5. Dickson RB, Lippman ME: Estrogenic regulation of growth and polypeptide growth factor secretion in human breast carcinoma. Endocr Rev 1987, 8:29-43.

6. Rochefort $\mathrm{H}$ : Biochemical basis of breast cancer treatment by androgens and progestins. In Hormones and Cancer. New York: Alan R Liss; 1984:79-95.

7. Satyaswaroop PG, Mortel R: Hormonal treatment of endometrial carcinoma: An overview and new development in biology. J Steroid Biochem Mol Biol 1990, 37:997-1001.

8. McGuire WL, Horwitz KB: A role of progesterone in breast cancer. In Biochemical Actions of Progesterone and Progestins. Edited by Grupide E. New York: Annals of the New York Academy of Sciences; 1977:99-100.

9. Liang $P, P a r d e e ~ A B:$ Differential display of eukaryotic messenger RNA by means of the polymerase chain reaction. Science 1992, 257:967-971.

10. Vindelov LL, Christensen IJ, Nissen NI: A detergent-trypsin method for the preparation of nuclei for flow cytometric DNA analysis. Cytometry 1983, 3:323-327.

11. Murphy LC, Dotzlaw H: Endogenous growth factor expression in T-47D, human breast cancer cells, associated with reduced sensitivity to antiproliferative effects of progestins and antiestrogens. Cancer Res 1989, 49:599-604.

12. Musgrove EA, Lee CSL, Sutherland RL: Progestins both stimulate and inhibit breast cancer cell cycle progression while increasing expression of transforming growth factor a, epidermal growth factor receptor, c-fos and c-myc genes. Mol Cell Biol 1991, 11:5032-5043.

13. Koga $M$, Musgrove EA, Sutherland RL: Modulation of the growth-inhibitory effect of progestins and the antiestrogen hydroxyclomiphene on human breast cancer cells by epidermal growth factor and insulin. Cancer Res 1989, 49:112-116.

14. Sarup JC, Rao KV, Fox CF: Decreased progesterone binding and attenuated progesterone action in cultured human breast carcinoma cells treated with epidermal growth factor. Cancer Res 1988, 48:5071-5078.
15. Kester HA, ven der Leede B-JM, van der Saag PT, van der Burg B: Novel progesterone target genes identified by an improved differential display technique suggest that progestin-induced growth inhibition of breast cancer cells coincides with enhancement of differentiation. J Biol Chem 1997, 272:16637-16643.

16. Virata MLA, Wagner RM, Parry DAD, Green KJ: Molecular structure of the human desmoplakin I and II amino terminus. Proc Natl Acad Sci USA 1992, 89:544-548.

17. Chidgey MAJ: Desmosomes and disease. Histol Histopathol 1997, 12:1159-1168.

18. Mueller $\mathrm{H}$, Franke WW: Biochemical and immunological characterization of desmoplakins I and II, the major polypeptides of the desmosomal plaque. J Mol Biol 1983, 163:647-671.

19. Schwarz MA, Owaribe K, Kartenbeck J, Franke WW: Desmosomes and hemidesmosomes: constitutive molecular components. Annu Rev Cell Biol 1990, 6:461-491.

20. Green KJ, Stappenbeck S: The desmosomal plaque: role in attachment of intermediate filaments to the cell surface. In Molecular Mechanisms of Epithelial Cell Junctions. Edited by Citi SRG. Austin: Landes Company; 1994:157-171.

21. Jones JCR, Goldman RD: Intermediate filaments and the initiation of desmosome assembly. J Cell Biol 1985, 101:506-517.

22. Miller K, Mattey D, Measures H, Hopkings C, Garrod D: Localisation of the protein and glycoprotein components of bovine nasal epithelial desmosomes by immunoelectron microscopy. EMBO J 1987, 6:885-889.

23. Jackson BW, Grund C, Schmid E, Burki K, Franke WW, Illmensee $\mathrm{K}$ : Differentiation; research in biological diversity. Differentiation 1980, 17:161-179.

24. Garrod DR: Desmosomes and cancer. Cancer Surv 1995, 24: 97-111.

25. Franke WW, Moll R, Mueller H: Immunocytochemical identification of epithelium derived human tumours with antibodies to desmosomal plaque proteins. Proc Natl Acad Sci USA 1983, 80:543-547.

26. Green KJ, Stappenbeck TS, Noguchi S, Oyasu R, Nilles LA: Desmoplakin expression and distribution in cultured rat bladder epithelial cells of varying tumorigenic potential. Exp Cell Res 1991, 193:134-143.

27. Garrod DR: Immunohistochemical staining of desmosomal components in oral squamous cell carcinomas and its association with tumour behaviour. Br J Cancer 1996, 73:1491-1497.

28. Davies EL, Gee JMW, Cochrane RA, Jiang WG, Sharma AK, Nicholson RI, Mansel RE: The immunohistochemical expression of desmoplakin and its role in vivo in the progression and metastasis of breast cancer. Cancer Res 1999, 35:902-907.

29. Lin VC, Eng AS, Hen NE, Ng EH, Chowdhury SH: Effect of progesterone on the invasive properties and tumor growth of progesterone receptor-transfected breast cancer cells MDAMB-231. Clin Cancer Res 2001, 7:2880-2886.

30. Lin VC, Ng EH, Aw SE, Tan MG, Ng EH, Bay BH: Progesterone induces focal adhesion in breast cancer cells MDA-MB-231 transfected with progesterone receptor complementary DNA. Mol Endocrino/ 2000, 14:348-358.

31. Dai D, Wolf DM, Litman ES, White MJ, Leslie KK: Progesterone inhibits human endometrial cancer cell growth and invasiveness: down-regulation of cellular adhesion molecules through progesterone B receptors. Cancer Res 2002, 62:881-886.

32. Sheffield LG: Hormonal regulation of epidermal growth factor receptor content and signaling in bovine mammary tissue. Endocrinology 1998, 139:4568-4575.

33. Lange CA, Richer JK, Shen T, Horwitz KB: Convergence of progesterone and epidermal growth factor signaling in breast cancer. Potentiation of mitogen-activated protein kinase pathways. J Biol Chem 1998, 47:31308-31316

34. Richer JK, Lange CA, Manning NG, Owen G, Powell R, Horwitz $\mathrm{KB}$ : Convergence of progesterone with growth factor and cytokine signaling in breast cancer. Progesterone receptors regulate signal transducers and activators of transcription expression and activity. J Biol Chem 1998, 273:31317-31326.

\section{Correspondence}

Lee E Faber, Department of Physiology and Molecular Medicine, Medical College of Ohio, 3035 Arlington Avenue, Toledo, $\mathrm{OH} 43614$ 5804, USA. Tel: +1 419383 4584; fax: +1 419383 6168; e-mail: Ifaber@mco.edu 